BIS WORKING PAPERS

No. 88 - June 2000

\title{
EVIDENCE ON THE RESPONSE \\ OF US BANKS TO CHANGES \\ IN CAPITAL REQUIREMENTS
}

by

Craig Furfine

BANK FOR INTERNATIONAL SETTLEMENTS

Monetary and Economic Department

Basel, Switzerland 
BIS Working Papers are written by members of the Monetary and Economic Department of the Bank for International Settlements, and from time to time by other economists, and are published by the Bank. The papers are on subjects of topical interest and are technical in character. The views expressed in them are those of their authors and not necessarily the views of the BIS.

Copies of publications are available from:

Bank for International Settlements

Information, Press \& Library Services

CH-4002 Basel, Switzerland

Fax: +41 61 / 2809100 and +4161/2808100

This publication is available on the BIS website (www.bis.org).

(C) Bank for International Settlements 2000.

All rights reserved. Brief excerpts may be reproduced or translated provided the source is stated. 


\title{
BIS WORKING PAPERS
}

No. 88 - June 2000

\section{EVIDENCE ON THE RESPONSE \\ OF US BANKS TO CHANGES \\ IN CAPITAL REQUIREMENTS}

by

Craig Furfine *

\begin{abstract}
This paper develops a structural, dynamic model of a banking firm to analyse how banks adjust their loan portfolios over time. In the model, banks experience capital shocks, face uncertain future loan demand, and incur costs based on their proximity to regulatory minimum capital requirements. Non-linear relationships between bank capital levels and lending are derived from the model, and key parameters are estimated using panel data on large US commercial banks operating continuously between December 1989 and December 1997. Using the estimated model, the optimal bank response to changes in capital requirements, shocks to bank capital, and changes to bank loan demand is simulated. The simulations predict that increases in risk-based and leverage capital requirements, negative capital shocks, or a decline in loan demand cause a reduction in loan growth. Nevertheless, by calculating the optimal portfolio response to these various changes, it is shown that changes in capital regulation are a necessary ingredient to explain the decline in loan growth and the rise in bank capital ratios witnessed nearly a decade ago. Thus, this study suggests that the current effort to redesign bank capital requirements should work under the assumption that banks will optimally respond to the economic incentives found in the regulation.
\end{abstract}





\section{Contents}

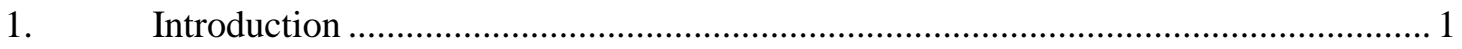

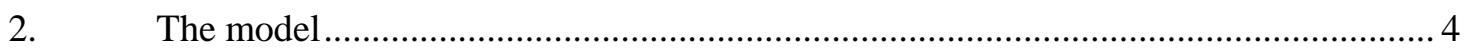

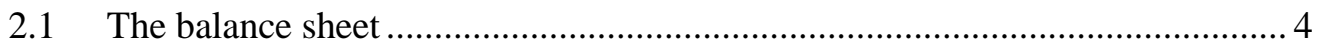

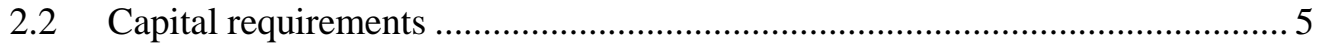

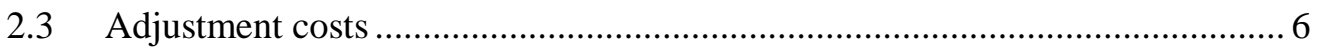

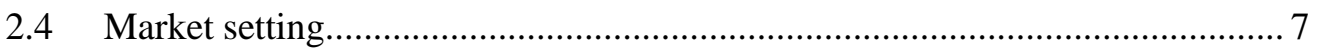

2.5 Uncertainty and the evolution of capital ...................................................

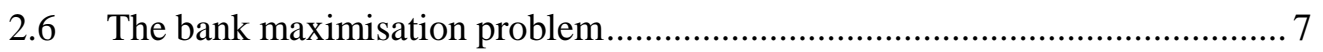

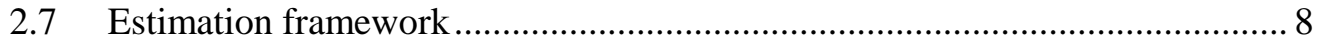

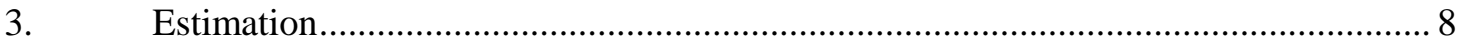

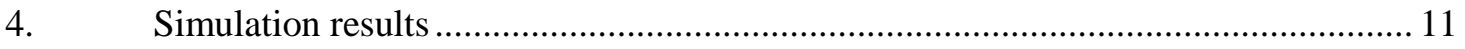

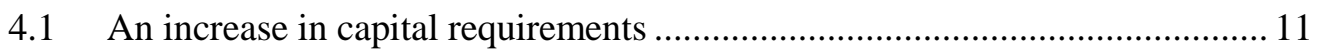

4.2 A negative shock to bank capital and a negative shock to loan demand......... 12

4.3 Implications for the last US credit crunch.................................................. 13

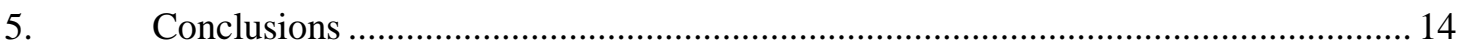

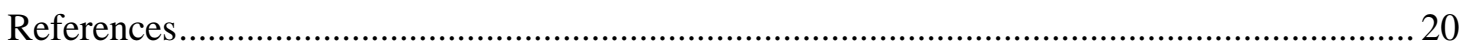





\section{Introduction}

Bank supervision and regulation have again become timely topics in the light of the current banking problems in many Asian nations. Banks in industrialised nations are thought to have been encouraged to lend excessively to banks in developing Asian economies because short-term interbank lending required a bank to fund only $1.6 \%$ of the loan with its own equity. ${ }^{1}$ The low capital requirement has been cited as a potential flaw in the current design of bank capital regulation (Greenspan [1998]). The attention that the Asian crisis has brought to bank capital requirements has encouraged William McDonough, current Chairman of the Basel Committee on Banking Supervision and President of the Federal Reserve Bank of New York, to announce a plan to completely overhaul bank capital requirements. $^{2}$ A successful overhaul of bank capital requirements calls for an understanding of the impact that the changes to capital requirements would have on the banks that are subject to them. This paper explores this issue by providing evidence on the response of banks to the last major overhaul of capital regulation.

The current environment for bank capital regulation is a result of the last overhaul of capital regulation, commonly referred to as the Basel Accord, which was agreed to in 1988 and implemented in the United States beginning in 1990. Since that time, central bankers, academics, and the financial press have tried to understand the significance of the Basel Accord, in particular, its introduction of risk-based capital requirements. The 1988 agreement mandated, for the first time, that banks hold a higher percentage of equity capital per loan than per government security. Because loans are presumably more risky than securities, these new capital regulations are thought to have improved the link between bank risk and bank capital. Given the common perception that equity capital is more costly than alternative funding sources such as deposits, these requirements made lending relatively more expensive than purchasing securities, thus providing an incentive for banks to shift their portfolios away from loans and into securities.

Shortly following the passing of the Basel Accord, a shift occurred in US commercial bank portfolios consistent with the new economic incentives given to bank managers. Banks simultaneously reduced their investments in commercial lending and began to hoard government securities. As shown in Figure 1, the share of total bank credit invested in commercial and industrial loans fell from around $22.5 \%$ in 1989 to under $16 \%$ in 1994 . The share of total bank credit invested in US government

1 According to the Basel capital standards, international interbank loans with a maturity less than one year attract a $20 \%$ risk weight. Since capital requirements are $8 \%$ of risk-weighted assets, these interbank loans require $20 \%$ x $8 \%=1.6 \%$ capital.

2 At this writing, a second consultative document for a revised capital accord is planned for early 2001. 
securities increased from just over $15 \%$ to nearly $25 \%$ over the same time period. Although the trend has been partially reversed since 1994, bank portfolios remain much less invested in commercial loans than they have been over the last 25 years. This period of portfolio shifting at banks has been popularly referred to as the "credit crunch".

In the midst of the bank portfolio adjustment, the US economy experienced a recession. Many questioned whether the recession-related negative shocks to bank capital or recession-related decline in loan demand was the proximate cause of the bank portfolio reallocation. Such alternative hypotheses would have to explain why the change in bank portfolio allocation occurred well before the onset of recession and continued well after the current US expansion had begun. Further, as Figure 1 indicates, the direction of the shift in bank portfolios was the reverse of what had typically occurred during previous economic downturns. During the recessions of 1974-75 and 1982, the share of bank credit invested in commercial and industrial lending rose while the share invested in government securities either fell or was nearly stable.

Thus, circumstantial evidence supports the view that the Basel Accord played a role in the US credit crunch. It is perhaps surprising, therefore, that there has been no definitive conclusion to this effect in the academic literature. ${ }^{3}$ The most popular approach in the literature has been to assume that the impact of changes in capital regulation can be inferred from the coefficient on capital in a regression of bank loan growth on measures of bank capital and various control variables for loan demand. Bernanke and Lown [1991], Hall [1993], Berger and Udell [1994], Haubrich and Wachtel [1993], Jacklin [1993], Hancock and Wilcox [1994], Brinkmann and Horvitz [1995], and Peek and Rosengren [1995a] use variations of this technique. Because of different sample periods, sample banks, control variables, and specifications for capital adequacy, the conclusions reached by these papers are mixed. In general, this strand of the literature finds that the empirical correlation between bank capital and bank lending is small when estimated in a cross-section sample of banks. However, because they lack a structural model of bank behaviour, these papers cannot formally estimate the impact of capital regulation or distinguish between changes in bank capital and changes in bank capital regulation. Further, they implicitly assume that correlation means causality. Authors that find a small correlation between lending and capital generally conclude that risk-based capital requirements have had a small impact on bank lending and most likely did not cause the credit crunch. Authors that find no correlation conclude that the Basel Accord has not changed the means by which banks allocate credit.

Trying to add more structure to previous empirical work, Shrieves and Dahl [1995] and Jacques and Nigro [1997] postulate supply equations for lending and assume a partial adjustment model for bank equity. With this limited structure placed on the data, the authors estimate dynamic equations for bank

3 For a useful summary of much of the empirical literature on this subject, see Basel Committee [1999]. 
lending. These authors find that a higher level of risk-based capital relative to a bank's target affects bank loan supply. Although the approach offers more in terms of distinguishing correlation from causality, their measures of capital adequacy cannot differentiate between changes in bank capital and changes in bank capital regulation, nor were theoretical justifications given for their baseline equations. A different approach was taken by Hancock, Laing, and Wilcox [1995]. They add structure to the earlier strand of literature by applying a vector autoregression model to estimate the dynamic response to bank capital shocks. Given the assumptions that come with this approach, the paper concludes that banks adjust capital ratios much faster than they adjust their loan portfolios. While suggesting that shocks to bank capital may significantly affect loan portfolios, the results cannot be extended to an analysis of the Basel Accord without assuming the equivalence of bank capital and bank capital regulation.

The theoretical literature on the impact of changing capital requirements is fairly disconnected from the aforementioned empirical work. Much of this work predates the implementation of risk-based capital requirements. Predominantly, the focus of such work, e.g. Flannery [1989], Furlong and Keeley [1989, 1990], Kim and Santomero [1988], and Koehn and Santomero [1980], was to describe the relationship between bank leverage requirements and bank risk-taking. Such research is difficult, if not impossible, to apply to the type of risk-based capital requirement regime that is analysed here. Thakor [1996] and Passmore and Sharpe [1994] develop static models which, for certain assumed parameter values, demonstrate that the increase in a risk-based capital requirement can cause a bank to shift from loans to securities. Neither of these models, however, was fitted to banking data to estimate how large actual portfolio shifts in response to capital requirement changes would be, nor can they be used to distinguish in the data what were the proximate causes of the observed reduction in bank loan growth. Nevertheless, they give theoretical support to the intuitive claim that a regulatory change that raises the cost of lending relative to alternative investments will lead to a decline in lending.

This paper tries to bridge the gap between the existing theoretical and empirical literature. First, the paper develops a structural, dynamic model of a banking firm that operates in an environment with risk-based capital requirements. In the model, banks invest in loans and risk-free securities while accepting deposits and issuing equity. Banks in this model also face capital shocks and uncertain future loan demand conditions. Most importantly, the model considers in detail the current state of US capital regulation, taking into account that banks face both a risk-based and a non-risk-based capital requirement. Optimal conditions relating bank lending growth, bank capital ratios, bank capital regulation, and loan demand are derived formally from a bank maximisation framework.

The paper then connects the theory of bank lending to the available data on US bank portfolios. Formally, first-order conditions of the model are estimated using panel data on the 362 FDIC-insured commercial banks with assets greater than \$1 billion that operated continuously from 1989 to 1997. The parameter estimates are then used to simulate the model, providing a structural-model-based 
estimate of the impact of changes in capital regulation, shocks to bank capital, and shocks to bank loan demand on bank portfolio allocation. Conditional on the underlying assumptions of the model, the results suggest that a fall in loan demand alone cannot explain all the observed movements in US bank portfolios. Further, the results suggest that although many factors may cause a decline in loan growth, only changes in capital regulation can simultaneously explain all of the shifts in bank portfolios that occurred in the United States nearly 10 years ago.

In addition to indicating that capital requirements played a role in the change in bank portfolio allocation documented above, the results of the paper provide a more general conclusion regarding bank capital regulation. In particular, the results suggest that banks strongly respond to the economic incentives found in capital regulation. In this sense, the conclusions are similar to those found in Wall and Peterson [1995] and Peek and Rosengren [1995b]. Wall and Peterson [1995] suggest that regulation had a more important impact on bank capital decisions than did market discipline. Peek and Rosengren [1995b] find that formal regulatory action had a significant impact on bank lending decisions, even after controlling for bank capital ratios. These papers lend support to the notion that capital regulation, broadly speaking, can significantly influence bank decision-making. These results, in addition to those presented here, suggest that any debate on new capital regulations should consider the possible impact of changing the economic incentives given to the banks being regulated.

The remainder of the paper is organised as follows. The model is detailed in Section 2 and estimated from a panel data set in Section 3. Simulation results are given in Section 4. Section 5 concludes.

\section{The model}

\subsection{The balance sheet}

Prior to risk-based capital (RBC) requirements, banks could only increase their regulatory capital ratios by either reducing assets or issuing equity. The introduction of RBC allowed a bank to increase its regulatory capital ratios by adjusting the composition of its assets, both on and off the balance sheet. For this reason, a model that analyses the risk-based capital requirements must disaggregate the assets of a bank. I assume that the asset side of a bank's balance sheet consists only of loans $L$ and default-free securities $S{ }^{4}$ The liability side of the balance sheet is made up of deposits $D$ and capital $K$. Thus, the balance sheet identity is $\mathrm{L}_{\mathrm{t}}+\mathrm{S}=\mathrm{D}_{\mathrm{t}}+\mathrm{K}_{\mathrm{t}}$, which must hold at all times $t$.

4 The model generalises to both $n$ asset types as well as the inclusion of off-balance sheet items. 


\subsection{Capital requirements}

There are two types of capital requirements. First, a bank faces a leverage requirement that mandates a minimum capital to total asset ratio.

$$
\text { (1) } \frac{K_{t}}{L_{t}+S_{t}}>C_{t}
$$

Second, a bank faces a risk-based capital requirement that can be written

$$
\text { (2) } \frac{K_{t}}{a_{t}}>d_{t}
$$

where the risk weight $a$ is known to the bank. The values $c_{t}$ and $d_{t}$ are the specified regulatory minimums at time $t^{5}$

Approaching either capital requirement is assumed increasingly costly to the bank. When a bank fails to meet its capital requirement, regulators impose a variety of restrictions on bank activities. For example, poorly capitalised banks cannot accept brokered deposits. In addition, regulators can require a capital-deficient bank to file a plan of recapitalisation that outlines a period during which the bank must take specific steps to improve its capital position. Such regulator sanctions impose real costs on bank equity owners and debt holders. These costs might include a reduction in the flow and size of dividends. In the extreme case, the bank could be taken over by the FDIC, reorganised, and then sold to another bank. The bank may even be liquidated. In such instances, debt holders may not recover their full principal invested in the bank.

Thus, failing to meet capital requirements imposes real costs on the uninsured claimholders of the bank. The closer a bank is to the regulatory minimum, the more likely these costs are to occur. As a simplification, I assume a continuous nature to these costs. That is, I do not assume that banks that are currently satisfying the requirements are unaffected by them. Defining $k_{t}^{R}$ and $k_{t}^{L}$ as the bank's riskbased and leverage capital ratios, respectively, where $\mathrm{K}_{t}^{R} \equiv \frac{\mathrm{K}_{t}}{\mathrm{aL}_{\mathrm{t}}}, \mathrm{k}_{\mathrm{t}}^{\mathrm{L}} \equiv \frac{\mathrm{K}_{\mathrm{t}}}{\mathrm{L}_{\mathrm{t}}+\mathrm{S}_{\mathrm{t}}}$, I specify the total costs implied by a bank's two capital ratios as

Currently the required leverage ratio, $c$, is $3 \%$. This $3 \%$ leverage requirement applies to banks with a CAMEL rating of 1. Baer and McElravey [1993] point out that banks typically have a leverage requirement closer to 5\%. The Tier 1 requirement is $4 \%$, while the total risk-based capital requirement is $8 \%$. 
(3) $\begin{aligned} & \left(a L_{t}\right) g\left(k_{t}^{R}-d_{t}\right) \text {, the bank's costs incurred by its RBC position, and } \\ & \left(L_{t}+S_{t}\right) h\left(k_{t}^{L}-c_{t}\right) \text {, the bank's costs incurred by its leverage position. }\end{aligned}$

The functions $g$ and $h$ measure the per dollar costs of approaching the capital requirements. Both $g$ and $h$ are assumed to be decreasing and convex to indicate that as a bank builds a cushion of capital relative to the regulatory minimums, it pays a decreasing per dollar cost. In other words, suppose the risk-based requirement, $d$, was raised from its current level of $4 \%$ to $5 \%$. A bank reporting a $6 \%$ ratio will incur an increase in cost more than a bank reporting a 15\% ratio. The per dollar risk-based capital costs $g$ are multiplied by total risk-weighted assets to account for the idea that only the risk-adjusted portion of lending is subject to this cost. The per dollar leverage requirement costs are multiplied by total assets to capture the fact that both loans and securities are subject to this requirement. Note that a bank investing entirely in zero risk-weighted securities would not pay any risk-based capital cost, but would still have costs associated with the leverage ratio. Finally, this model does not prohibit a bank from failing to meet either capital requirement.

\subsection{Adjustment costs ${ }^{6}$}

The model assumes that a bank pays adjustment costs when it adjusts the growth of its loan portfolio over time at a rate different from what is dictated by its loan demand. Specifically, banks pay a cost in the amount given by (4).

(4) $L_{t} j\left(l_{t}-\rho_{t}\right)$ are the adjustment costs of lending at time $t$

where $\mathrm{I}_{\mathrm{t}} \equiv \frac{\mathrm{L}_{\mathrm{t}}}{\mathrm{L}_{\mathrm{t}-1}}$ is the gross growth rate of lending at time $t$ and $\rho_{t}$ is a measure of loan demand at time $t$. The adjustment cost function $j$ is assumed to be convex, with a time-varying minimum at $\rho_{t}$.

Banks may incur costs from excessive shrinking either because of severing relationships of the type described in Diamond [1984] and Sharpe [1990] or because of their inability to continue to take advantage of the economies of scale as documented in Berger, Hancock, and Humphrey [1993]. Excessive growing of a loan portfolio may also be expensive as banks may be forced to lower their credit standards to accept more existing applicants. The variable $\rho$ is a proxy for loan demand. The functional form assumption implies that a loan portfolio change caused by a change in loan demand,

6 Without costs explicitly connecting the lending behaviour at time $t$ with that at $t+1$, the model would generate erratic patterns in bank lending that do not seem consistent with the data. These costs were assumed functions of the growth rates rather than changes in the level of lending to both better fit the data and to maintain consistency with earlier research. 
e.g. $l$ falling with $\rho$, is costless, but that loan portfolio changes caused by a change in supply, e.g. $l$ falling with $\rho$ constant, are costly.

\subsection{Market setting}

Apart from the previously mentioned adjustment costs, loans are assumed to pay interest at a fixed rate $r_{t}^{L}$. I further assume an unlimited supply of government securities is available to the bank at a rate $r_{t}^{S}$. I assume that deposits are available at a rate $r_{t}^{D}$. These interest rates may change over time to reflect changes to loan demand and supply $\left(r_{t}^{\mathrm{L}}\right)$, risk-free interest rates $\left(r_{t}^{S}\right)$, or deposit demand and supply $\left(r_{t}^{D}\right)$.

\subsection{Uncertainty and the evolution of capital}

Bank capital $K$ evolves by

$$
\text { (5) } K_{t}=K_{t-1}+r_{t}^{L} L_{t}+r_{t}^{S} S_{t}-r_{t}^{D} D_{t}+Q_{t}+\varepsilon_{t}
$$

where $Q_{t}$ represents the amount of net equity issuing. ${ }^{7}$ Equation (5) implies that capital accumulates independent of adjustment costs $j$. That is, adjustment costs are incurred by management rather than bank equity holders. For later use, it is helpful to rewrite (5) in a normalised form given by $\left(5^{\prime}\right)$.

$$
\text { (5') } k_{t}^{R}=\left(\frac{1}{1-r_{t}^{D}}\right)\left(\frac{k_{t-1}^{R}}{l_{t}}+\frac{1}{a}\left(r_{t}^{L}-r_{t}^{D}\right)+\frac{1-s_{t}}{a s_{t}}\left(r_{t}^{S}-r_{t}^{D}\right)+\frac{q_{t}}{a s_{t}}\right)+\varepsilon_{t}^{\prime}
$$

where $q_{t} \equiv Q_{t} /\left(L_{t}+S_{t}\right)$ and $s_{t} \equiv L_{t} /\left(L_{t}+S_{t}\right)$.

At the beginning of time $t$, the bank observes prevailing interest rates as well as the current period capital shock, $\varepsilon_{t}$. The bank forms expectations as to the future interest rates, future capital shocks, and future loan demand. With these observable variables and their expectations, the bank chooses its lending, the quantity of default-free securities to buy, and the amount of equity to issue. These decisions determine the reported end of period capital ratio as given by $\left(5^{\prime}\right)$.

\subsection{The bank maximisation problem}

Banks maximise the present discounted value of future profits, less adjustment costs, costs of issuing equity, and costs incurred via their capital position. Specifically, the bank's maximisation problem is 
(6)

$$
\left.\left\{L_{t}, S_{t}, Q_{t}\right\}\right|_{t=1} ^{\infty} E \sum_{t=1}^{\infty} \beta^{t}\left(\begin{array}{c}
r_{t}^{L} L_{t}-L_{t} j\left(l_{t}-\rho_{t}\right)+r_{t}^{S} S_{t}-r_{t}^{D} D_{t} \\
-a L_{t} g\left(k_{t}^{R}-d_{t}\right)-\left(L_{t}+S_{t}\right) h\left(k_{t}^{L}-c_{t}\right)-Q_{t} \lambda\left(q_{t}\right)
\end{array}\right)
$$

subject to (5)

where $\lambda\left(q_{t}\right)$ is the per dollar costs of issuing equity in an amount $q$ and $\beta$ is the discount factor.

\section{7 $\quad$ Estimation framework}

Substituting (5) into (6) and taking derivatives with respect to lending $L$, securities $S$, and equity issuing $Q$, yields the following first-order conditions:

$$
\begin{aligned}
& \left(\frac{r_{t}^{L}-r_{t}^{D}}{1-r_{t}^{D}}\right)\left(1-g^{\prime}\left(k_{t}^{R}-d_{t}\right)-h^{\prime}\left(k_{t}^{L}-c_{t}\right)\right)-a_{t}\left[g\left(k_{t}^{R}-d_{t}\right)-g^{\prime}\left(k_{t}^{R}-d_{t}\right)\right] \\
& -\left[h\left(k_{t}^{L}-c_{t}\right)-k_{t}^{L} h^{\prime}\left(k_{t}^{L}-c_{t}\right)\right]+q_{t}^{2} \lambda^{\prime}\left(q_{t}\right)-\left[l_{t} j^{\prime}\left(l_{t}-\rho_{t}\right)+j\left(l_{t}-\rho_{t}\right)\right]=-\beta E_{t} l_{t+1}^{2} j^{\prime}\left(l_{t+1}-\rho_{t+1}\right) \\
& \text { (8) }\left(\frac{r_{t}^{S}-r_{t}^{D}}{1-r_{t}^{D}}\right)\left(1-g^{\prime}\left(k_{t}^{R}-d_{t}\right)-h^{\prime}\left(k_{t}^{L}-c_{t}\right)\right)-\left[h\left(k_{t}^{L}-c_{t}\right)-k_{t}^{L} h^{\prime}\left(k_{t}^{L}-c_{t}\right)\right]+q_{t}^{2} \lambda^{\prime}\left(q_{t}\right)=0 \\
& \text { (9) }\left(\frac{1}{1-r_{t}^{D}}\right)\left(r_{t}^{D}-g^{\prime}\left(k_{t}^{R}-d_{t}\right)-h^{\prime}\left(k_{t}^{L}-c_{t}\right)\right)-q_{t} \lambda^{\prime}\left(q_{t}\right)-\lambda\left(q_{t}\right)=0
\end{aligned}
$$

Equation 7 equates the marginal change in the (discounted) future adjustment costs to the current marginal return on lending net of the cost of meeting both capital requirements and issuing equity. Equation 8 equates the marginal return to securities with the marginal capital requirement costs and equity costs. Equation 9 ensures the optimal issuance of new equity capital.

\section{Estimation}

The data used in the estimation come from the Bank Call Reports. The data used are quarterly, beginning in September 1989 and continuing through December 1997. March 1990 was the first date at which risk-based capital data were collected. For this reason, it is not possible to estimate the model

\footnotetext{
Dividends can be interpreted as a negative value of $Q_{t}$.
} 
for a period before the change in capital requirements using precise measures of bank capital levels. The sample consists of the 362 FDIC-insured commercial banks with December 1989 assets greater than $\$ 1$ billion and has been adjusted for mergers. Observations with risk-based or leverage capital ratios above $25 \%$, leverage capital ratios below $5 \%$, or risk-based rations below $4 \%$ were dropped, as were observations with quarterly loan growth either above $100 \%$ or below $-50 \%$. Thus, the results are not being influenced by unhealthy banks whose decisions may be mandated by supervisors or by strange institutions with exceptionally high capital or unusually high or low loan growth.

Lending growth was calculated using total Commercial and Industrial (C\&I) lending. Estimates of bank equity issuance, $q$, are calculated from $\left(5^{\prime}\right)$. Values for $\rho_{t}$ were estimated as the average loan growth for banks in the same region as the given bank. Interest rates were measured as the weighted average effective loan rate on all commercial and industrial loans taken from the Federal Reserve's quarterly Survey of Terms of Bank Lending $\left(r_{t}^{L}\right)$, the rate on the two-year constant maturity treasury note $\left(r_{t}^{S}\right)$, and the rate on secondary market six-month CDs $\left(r_{t}^{D}\right)$. For the results reported, I used the following functional forms for the cost of risk-based capital requirements, the cost of leverage capital requirements, the adjustment costs of lending, and the cost of issuing equity. ${ }^{8}$

$$
\begin{aligned}
& g(.)=\eta_{0}-\eta_{1} \ln \left(k_{t}^{R}-(d+\hat{d})\right) \\
& h(.)=v_{0}-v_{1} \ln \left(k_{t}^{L}-(c+\hat{c})\right) \\
& j\left(l_{t}-\rho_{t}\right)=\frac{1}{2} \alpha\left(l_{t}-\rho_{t}\right)^{2} \\
& \lambda\left(q_{t}\right)=\theta_{0}+\frac{1}{2} \theta_{1}\left(q_{t}-\bar{q}\right)^{2}
\end{aligned}
$$

Theory predicts that $\eta_{1}, v_{1}, \alpha, \theta_{1}>0$. The parameters $\eta_{1}$ and $v_{1}$ influence the marginal cost of the bank's capital positions. The higher the parameter $\eta_{1}$, the more costly an increase in the required riskbased capital requirement would be. Likewise, the higher $v_{1}$, the more costly an increase in the leverage capital requirement would be. The parameters $\hat{c}$ and $\hat{d}$ are fixed and known to the bank but will need to be estimated. These two parameters simply allow a larger family of curves to be fitted to the data. The parameter $\alpha$ determines the curvature of the adjustment costs. The parameter $\theta_{1}$ measures the marginal cost of issuing equity to an extent different from the industry's overall equity issuing posture, $\bar{q}$, measured as the average level of $q_{t}$ over the sample period.

With these functional form specifications and using the fact that, for C\&I lending, $a=1$, (7) and (8) can be written as regression equations 


$$
\begin{gathered}
\left(\frac{r_{t}^{L}-r_{t}^{D}}{1-r_{t}^{D}}\right)\left(1+\frac{\eta_{1}}{k_{t}^{R}-\left(d_{t}+\hat{d}\right)}+\frac{v_{1}}{k_{t}^{L}-\left(c_{t}+\hat{c}\right)}\right)+\left[n_{1} \ln \left(k_{t}^{R}-\left(d_{t}+\hat{d}\right)\right)-\frac{\eta_{1}}{k_{t}^{R}-\left(d_{t}+\hat{d}\right)}\right] \\
(11)+\left[v_{1} \ln \left(k_{t}^{L}-\left(c_{t}+\hat{c}\right)\right)-\frac{v_{1}}{k_{t}^{L}-\left(c_{t}+\hat{c}\right)}\right]+q_{t}^{2} \theta_{1}\left(q_{t}-\bar{q}\right)-\left[l_{t} \alpha\left(l_{t}-\rho_{t}\right)+\frac{1}{2} \alpha\left(l_{t}-\rho_{t}\right)^{2}\right] \\
+\beta l_{t+1}^{2} \alpha\left(l_{t+1}-\rho_{t+1}\right)=\mu_{1 \mathrm{t}} \\
\left(\begin{array}{c}
\left(\frac{r_{t}^{S}-r_{t}^{D}}{1-r_{t}^{D}}\right)\left(1+\frac{\eta_{1}}{k_{t}^{R}-\left(d_{t}+\hat{d}\right)}+\frac{v_{1}}{k_{t}^{L}-\left(c_{t}+\hat{c}\right)}\right)+ \\
{\left[+v_{1} \ln \left(k_{t}^{L}-\left(c_{t}+\hat{c}\right)\right)-\frac{v_{1}}{k_{t}^{L}-\left(c_{t}+\hat{c}\right)}\right]+q_{t}^{2} \theta_{1}\left(q_{t}-\bar{q}\right)=\mu_{2 t}}
\end{array}\right.
\end{gathered}
$$

for bank $i$ at time $t$ where

$$
\text { (13) } \begin{aligned}
& \mu_{1 t}=e_{i t}+\eta_{0}+v_{0}+p_{i t}^{1} \\
& \mu_{2 t}=v_{0}+p_{i t}^{2}
\end{aligned}
$$

where $e_{i t}$ is a pure expectation error for bank $i$ at time $t$, and $p_{i t}^{m}$ represents a bank-specific specification error in equation $m$ for bank $i$ at time $t$. I have further assumed that $p_{i t}^{m}$ contains a common, bank-specific, time-invariant factor in both equations. That is, I allow each bank in the sample to have a fixed deviation from the optimal first-order conditions as specified in the model. Thus, I estimate the system given by (11)-(13) using Seemingly Unrelated Regression allowing for common fixed effects. Reported standard errors have also been corrected for potential heteroskedasticity and serial correlation using the method of Newey and West [1987].

As one can see from (11)-(13), the parameters $\eta_{1}, v_{1}, \alpha, \hat{d}, \hat{c}, \theta_{1}$ are identified by the model. The discount factor $\beta$, although identified, was chosen to be .975 , corresponding to a rate of time preference around $10 \%$ as time is measured in quarters. Table 1 presents the estimates. Note that with the exception of $\theta_{1}$, all of the estimated parameters are statistically significant and of the correct sign.

To obtain a better sense as to the meaning of the parameter values, I plot in Figure 2 the estimated marginal cost of the two capital requirements. The downward sloping shape results from the estimated convexity of the functions $g$ and $h$. For example, the marginal benefit of a large bank increasing its risk-based capital ratio from $8 \%$ to $9 \%$ is 40 basis points (four tenths of one cent) per dollar of riskweighted assets. That is, lending is 40 basis points more costly for a bank at an $8 \%$ risk-based capital ratio than for one at $9 \%$. As one can see, the marginal cost declines with bank capital levels. The

Different functional forms were tried and did not significantly change the results presented. 
marginal cost of leverage requirements for large banks is noticeably higher than the cost of risk-based requirements. For example, a bank that increases its leverage capital ratio from $8 \%$ to $9 \%$ derives a 75 basis point benefit per dollar of assets. Finally note that non-linearity is important near the regulatory minimum ratios. As bank capital ratios fall towards the regulatory minimum, the model estimates that significant costs arise. At a 5\% ratio, the marginal cost of leverage requirements are estimated to be 3 full percentage points whereas the marginal cost risk-based requirements are estimated to be about $1 \frac{1 / 4}{4}$ percentage points.

\section{Simulation results}

Equations (7)-(9) and $\left(5^{\prime}\right)$ are a complete representation of the model. Using the parameter estimates given in Table 1 plus some assumed values for unidentified parameters, the model can be simulated to give predictions as to the impact of changes to regulatory minimum capital ratios. Table 2 below gives the assumed values of the unidentified parameters and the resulting steady state solution for loan growth, capital ratios, and the new equity to asset share that will be used in the simulations presented. The unidentified parameters were chosen to roughly match the steady state values for loan growth, capital ratios, and the new equity ratio of the bank with actual data for loan growth and capital ratios and the model's estimate for new equity issuing. Expectations of future interest rates were assumed to be equal to their steady state levels.

The marginal cost of bank capital requirements depicted in Figure 2 is a function not only of the parameter estimates given in Table 1 , but also of the regulatory minimum requirements. This can be seen in (10). Suppose the risk-based capital requirement $d$ was increased by $1 \%$. This would increase the marginal cost of risk-based capital requirements at every risk-based capital ratio. A bank would then reoptimise since its previous capital ratios were determined under the previous capital requirement regime. In this model, there is no sense in which certain capital requirements are "binding". In particular, even banks operating above the capital requirement will still adjust their portfolio in response to a capital requirement change. ${ }^{9}$

\subsection{An increase in capital requirements}

I first describe the simulated effect of a $1 \%$ increase in either the risk-based or leverage capital requirement. Figure 3 plots both dynamic paths of loan growth, security growth, and new equity

9 In general, changes to the capital requirement parameters would generate a new steady state solution. To keep the steady state growth rate of the loan portfolio constant, the simulations involving increases to risk-based capital requirements also include a slight increase in the rate of interest on loans. The simulations involving increases to leverage requirements also include a slight increase in the rate of interest on loans and securities. 
issuing relative to their behaviour in the original steady state. The top panel of Figure 3 reveals that the response of lending growth is quite similar for an increase in either capital requirement. Loan growth is reduced by $4.68 \%$ and $5.46 \%$ immediately following a $1 \%$ increase in the leverage and riskbased requirement respectively.

The middle and bottom panels, however, demonstrate that the model predicts quite different portfolio behavior depending on which capital requirement is increased. The model bank responds to an increase in leverage requirements with a decrease in securities growth, whereas a tremendous increase in securities growth follows a rise in risk-based requirements. Intuitively, these opposite reactions are due to the fact that securities count towards leverage ratios but are ignored in risk-based calculations. The reaction in the securities portfolio is also quite extreme. Following an increase in leverage capital requirements, securities growth is reduced by nearly $50 \%$. Following higher risk-based requirements, securities growth increases by nearly $35 \%$. These larger percentage changes are driven both by the lack of adjustment costs assumed in the model, and by the fact that securities make up a smaller proportion of the overall portfolio. Therefore, substantive portfolio changes require significant changes in growth rates.

The two capital requirement changes also have opposite effects regarding equity issuing. Equity issuing rises in response to an increase in risk-based capital requirements. This is the only alternative the bank has to boost its capital ratios in addition to reducing its loan portfolio. Equity issuance actually falls following an increase in leverage requirements. Because securities are costless to adjust, the model bank prefers to raise its leverage ratio by reducing securities rather than issuing additional equity. The optimal bank response actually entails curtailing equity issuing, which saves the cost of issuing equity, and reducing securities. Unlike loan and security growth, the new steady state values for equity have changed slightly - increasing following a rise in the risk-based capital requirement and falling following a rise in the leverage requirement.

Although not shown in Figure 3, the optimal bank response to a rise in either capital requirement translates to an analogous increase in the bank capital ratios. That is, the bank's risk-based capital ratio rises from $9 \%$ to $10 \%$ following a $1 \%$ rise in the risk-based requirement. Similarly, the bank's leverage ratio rises from $6.5 \%$ to $7.5 \%$ following a $1 \%$ risk in the leverage requirement.

\subsection{A negative shock to bank capital and a negative shock to loan demand}

This section investigates two other shocks to the bank steady state that one may be interested in exploring. Conceivably, a negative shock to bank capital or a negative shock to bank loan demand might cause a reduction in bank lending growth. The results from these two shocks are graphed in Figure 4. Consider first a negative shock to capital of a size equalling $1 \%$ of risk-weighted assets. In other words, the shock is the size that in the absence of bank adjustment would lower the bank's risk- 
based capital ratio by $1 \%$. The top panel of Figure 4 reveals that the response of lending growth is identical to what is predicted by a $1 \%$ increase in the risk-based capital requirement. Loan growth falls immediately by $5.47 \%$. Intuitively, the costs of capital requirements are assumed to be functions of a bank's capital cushion. Thus, a negative shock to capital might be expected to have similar consequences as a shock to capital requirements. Unlike changes to capital requirements, however, shocks to capital are temporary, and can be essentially undone by portfolio adjustment. Unlike large changes in securities growth following changes to capital requirements, the fall of securities growth here is also $5.47 \%$. The reduction in bank assets is combined with a noticeable temporary increase in the new equity issuing rate. Overall, the bank's response is enough to leave the simulated bank's capital ratios unchanged, despite the negative capital shock.

The model was then simulated with a $1 \%$ negative shock to loan demand (e.g. the parameter $\rho$ ) that was phased out over four quarters. ${ }^{10}$ That is, loan demand is presumed to return to its baseline value after four quarters. A shock of this magnitude has a noticeable yet small effect on the asset portfolio. Both loans and securities fall by about $.5 \%$. Gradually, loan and securities growth returns to the baseline when the shock to loan demand is over. New equity issuing falls in reaction to a negative loan demand shock. Since fewer profitable opportunities are needing funding, capital issuing can fall and the bank can still maintain its capital ratios at their original levels.

\subsection{Implications for the last US credit crunch}

The simulations in the previous two subsections indicate that a variety of different factors cause a decline in the growth rate of lending. However, each of the shocks considered e.g. (1) increase in riskbased capital requirements, (2) increase in leverage requirements, (3) negative shock to bank capital, and (4) negative shock to loan demand - has different implications with regard to securities growth, capital ratios, and equity issuing. Although the magnitude of the various effects is largely determined by the size of the shock, the direction of the changes is not. These qualitative results as well as what occurred in the United States during the early 1990s are summarised in Table 3.

The shocks considered in this paper are essentially the suggestions that have been made in the literature as to the possible causes of the US credit crunch that occurred nearly 10 years ago. The results from the model simulations, however, suggest that some explanations of what occurred in the US banking industry are more likely than others. In particular, only changes to capital requirements cause a bank to optimally increase its capital ratios. Shocks to capital or loan demand are by definition temporary, and the model predicts no long-term effect on bank loan growth and capital ratios. An increase in risk-based capital ratios can explain most of the actual experience, although it

10 A similar simulation involving the rate of return on loans was conducted. The results were qualitatively similar. 
cannot explain a rise in bank leverage ratios. A likely scenario, however, is that, at the time of the Basel Accord, not only were risk-based capital requirements introduced, but it could be argued that effective leverage requirements were tightened and regulators sought to enforce existing capital regulation more vigorously (Bizer [1993]). The model simulations suggest that implementation of risk-based capital requirements and a simultaneous, yet perhaps smaller, rise in (effective) required leverage ratios would be sufficient to explain the dramatic portfolio adjustment that occurred in US commercial bank portfolios. ${ }^{11}$

\section{Conclusions}

This paper develops a dynamic model of a banking firm in an environment with risk-based and leverage capital requirements. Implications of the model are estimated using data on US commercial banks to derive estimates of the marginal cost of bank capital requirements. These estimates are then used to derive structural estimates of the impact of changes in capital requirements on bank lending growth and capital ratios. The results demonstrate that changes in bank capital requirements are a necessary ingredient to explain the documented shifts in US commercial bank portfolios. In particular, it was shown that neither a fall in loan demand nor shocks to bank capital can simultaneously explain a decline in lending and a rise in bank capital ratios.

Whereas the empirical relationship between bank capital and bank lending has been well established, this paper develops a theoretical basis for that empirical regularity. By developing a formal model that incorporates capital regulation, capital shocks, and loan demand, alternative hypotheses for the observed decline in bank lending can be examined. The conclusions from this paper support the intuitive notion that changes to a bank's incentives will cause a change in bank behaviour. This result should be appreciated in the light of the current review of bank capital requirements.

11 These results do not preclude the possibility that changing loan demand influenced bank portfolios, but only preclude that a decline in loan demand alone can explain all of the actual portfolio adjustments. 
Figure 1: Bank portfolio allocation

Share of total bank credit

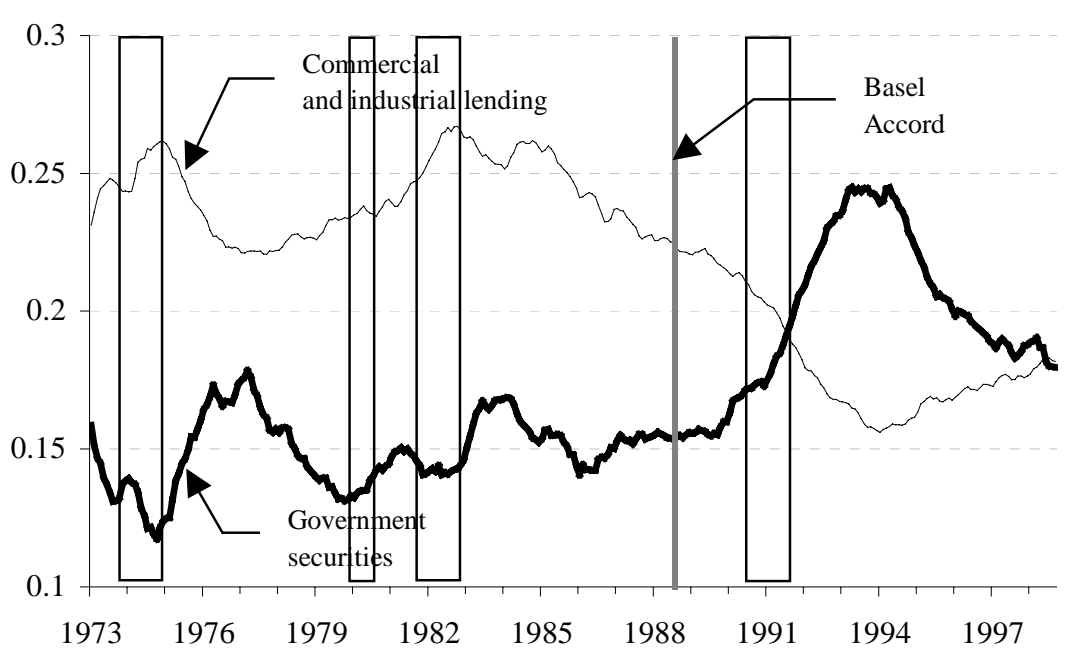

[Note: Recessions are boxed.]

Source: Federal Reserve H8.

Figure 2: Marginal cost of capital requirements

Cost (basis points)

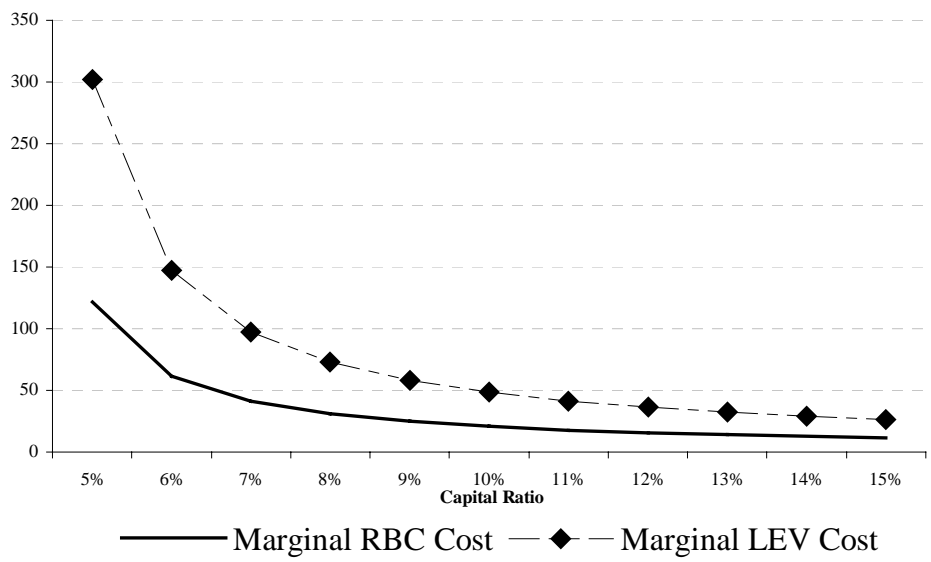


Figure 3: The impact of a $1 \%$ increase in capital requirements on loan growth, securities growth, and equity issuing
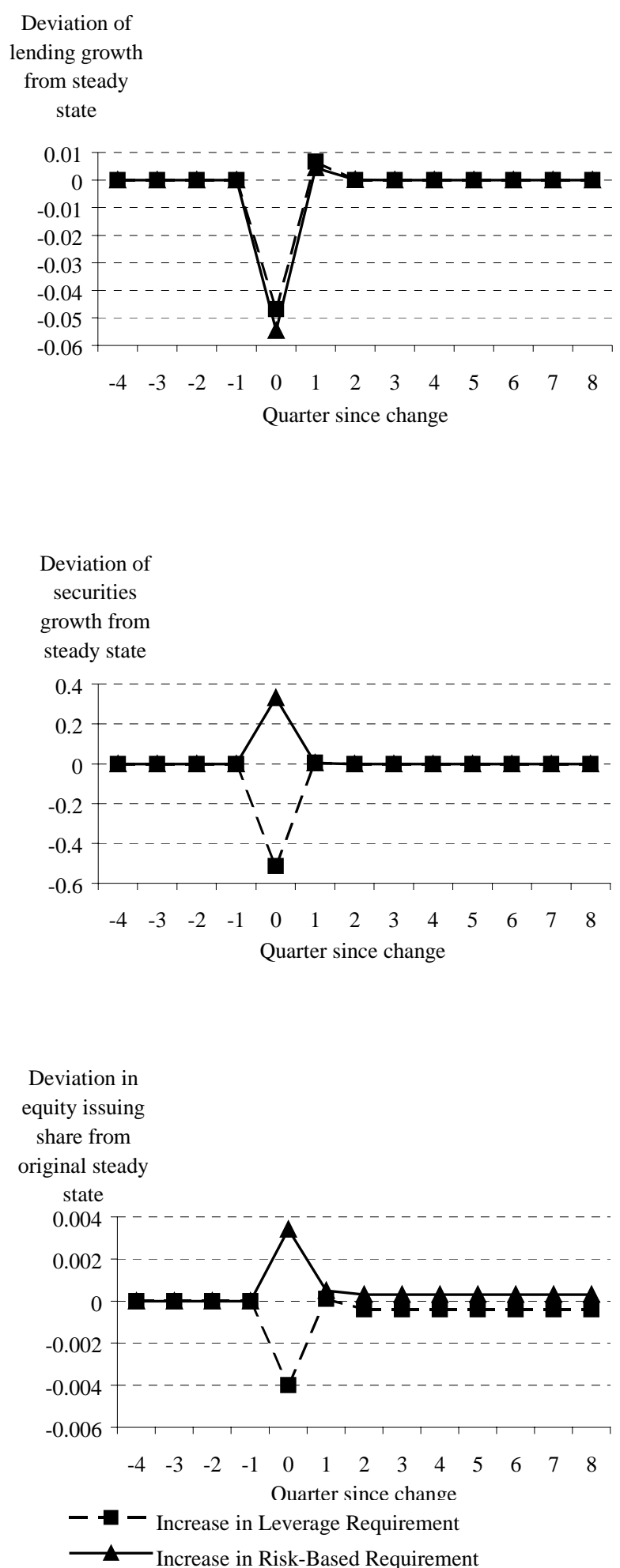
Figure 4: The impact of a 1\% negative shock to bank capital and a $1 \%$ negative shock to loan demand on loan growth, securities growth, and equity issuing
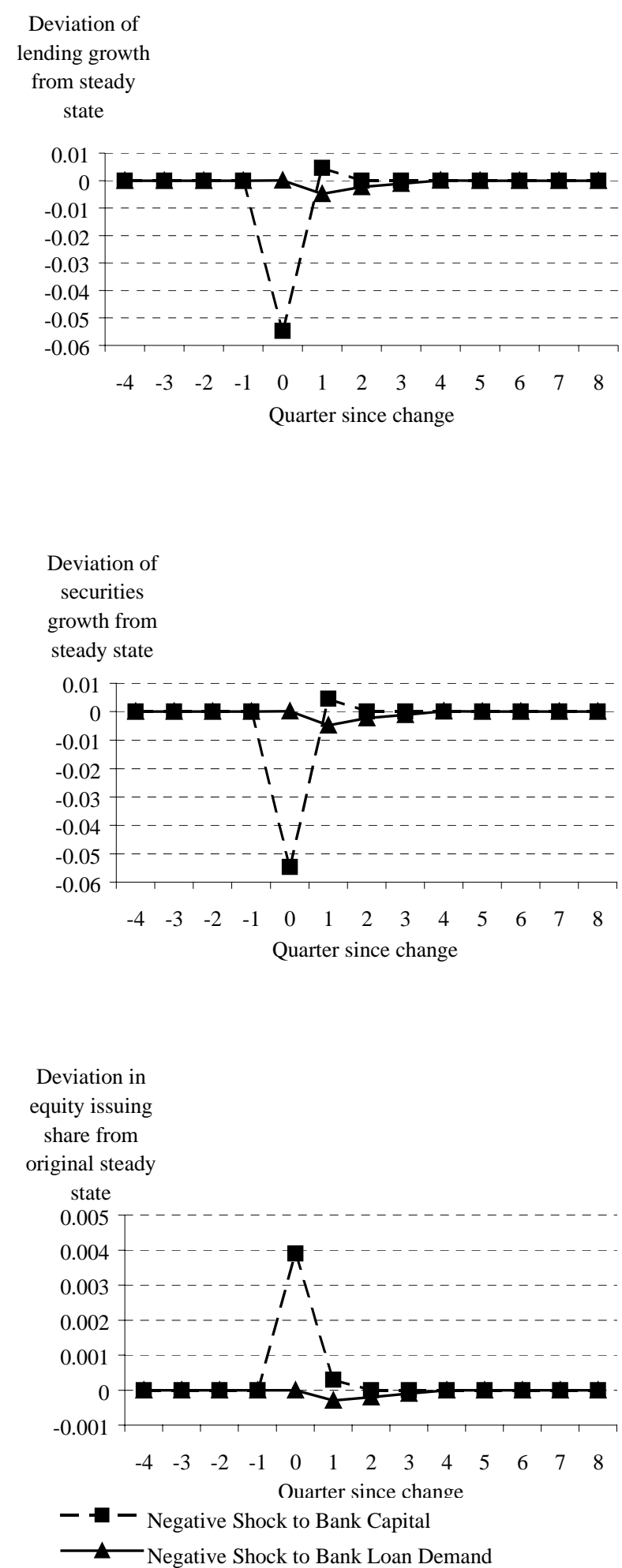
Table 1: Parameter estimates

\begin{tabular}{lcc}
\hline$\eta_{1}$ & Marginal RBC cost & $.000126^{* *}$ \\
& & $(.000058)$ \\
$\mathrm{d}+\hat{\mathrm{d}}$ & Point of infinite RBC cost & $.0396^{* *}$ \\
& & $(.0045)$ \\
$v_{1}$ & Marginal leverage cost & $.000288^{* *}$ \\
& & $(.000066)$ \\
$\mathrm{C}+\hat{\mathrm{c}}$ & Point of infinite leverage cost & $.0405^{* *}$ \\
& & $(.0022)$ \\
$\alpha$ & Adjustment cost parameter & $.000155^{* *}$ \\
& & $.000075)$ \\
$\theta_{1}$ & Equity issuing cost parameter & .0775 \\
& & $(.3642)$ \\
\hline
\end{tabular}

Heteroskedasticity and serial correlation consistent standard errors in parentheses.

** Denotes statistical significance at the $1 \%$ level.

Table 2: Implied steady state solutions

\begin{tabular}{cc}
\hline Parameter & Assumed value \\
$r^{L}$ rate of return on loans ${ }^{12}$ & .0100721 \\
$r^{S}$ rate of return on securities & .0060309 \\
$r^{D}$ rate of return on deposits & .005 \\
$\theta_{0}$ equity issuance parameter & .0193349 \\
$\bar{q}$ equity issuance parameter & -.0028728 \\
$\rho$ adjustment cost parameter & 1.02 \\
$\eta_{0}$ risk-based requirement cost parameter & .0035176 \\
$v_{0}$ leverage requirement cost parameter & -.0007798 \\
$\quad$ Steady state variables & \\
$l$ growth rate & Derived values \\
$k^{R} \quad$ risk-based capital ratio & $1.83 \%$ \\
$k^{L}$ leverage ratio & $9.00 \%$ \\
$\lambda$ new equity as a share of assets & $6.50 \%$ \\
\hline
\end{tabular}

12 These interest rates are quarterly and imply an annual return on assets of around .66\%, which is below the mean level of $.93 \%$ for all large banks in my sample. 
Table 3: Summary of simulation results and comparison to actual experience

\begin{tabular}{lccccc}
\hline & $\begin{array}{c}\text { Loan } \\
\text { growth }\end{array}$ & $\begin{array}{c}\text { Securities } \\
\text { growth }\end{array}$ & $\begin{array}{c}\text { Risk-based } \\
\text { capital ratio }\end{array}$ & $\begin{array}{c}\text { Leverage } \\
\text { capital ratio }\end{array}$ & $\begin{array}{c}\text { Equity } \\
\text { issuing }\end{array}$ \\
$\begin{array}{l}\text { Increase in Risk-Based } \\
\text { Capital Requirement }\end{array}$ & Fall & Rise & Rise & No effect & Rise \\
$\begin{array}{l}\text { Increase in Leverage } \\
\text { Capital Requirement }\end{array}$ & Fall & Fall & No effect & Rise & Fall \\
$\begin{array}{l}\text { Negative Shock to } \\
\text { Bank Capital }\end{array}$ & Fall & Fall & No effect & No effect & Rise \\
$\begin{array}{l}\text { Negative Shock to } \\
\text { Loan Demand }\end{array}$ & Fall & Fall & No effect & No effect & Fall \\
$\begin{array}{l}\text { Actual Experience } \\
1989-1992\end{array}$ & Fall & Rise & Rise & Rise & Rise \\
\hline
\end{tabular}




\section{References}

Baer, Herbert L. and McElravey, John [1993], "Capital Shocks and Bank Growth-1973 to 1991," Economic Perspectives, Federal Reserve Bank of Chicago, 1-21.

Basel Committee on Banking Supervision [1999], "Capital requirements and bank behaviour: the impact of the Basel Accord," working paper no. 1.

Berger, Allen N., Diana Hancock, and David B. Humphrey [1993], "Bank Efficiency Derived from the Profit Function," Journal of Banking and Finance, vol. 17, 317-347.

Berger, Allen N. and Gregory F. Udell [1994], "Did Risk-Based Capital Allocate Bank Credit and Cause a 'Credit Crunch' in the U.S.?” Journal of Money, Credit, and Banking, vol. 26, 585-628.

Bernanke, Ben and Cara Lown, "The Credit Crunch," Brookings Papers on Economic Activity, 1991, vol. 2, 205-247.

Bizer, David S. [1993], "Regulatory Discretion and the Credit Crunch," Working Paper U.S. Securities and Exchange Commission.

Brinkman and Horvitz [1995], "Risk-based Capital Standards and the Credit Crunch," Journal of Money, Credit, and Banking, vol. 27, 848-863.

Diamond, Douglas W. [1984], "Financial Intermediation and Delegated Monitoring," Review of Economic Studies, vol. 51, 393-414.

Flannery, Mark J. [1989], “Capital Regulation and Insured Banks' Choice of Individual Loan Default Risks," Journal of Monetary Economics, vol. 24, 235-258.

Furlong, Frederick and Keeley, Michael [1989], "Capital Regulation and Bank Risk-Taking: A Note," Journal of Banking and Finance, 883-91.

Furlong, Frederick and Keeley, Michael [1990], "A Reexamination of Mean-Variance Analysis of Bank Capital Regulation," Journal of Banking and Finance, 69-84.

Greenspan, Alan [1998], Remarks at the $34^{\text {th }}$ Annual Conference on Bank Structure and Competition, Federal Reserve Bank of Chicago.

Hall, Brian [1993], "How Has the Basel Accord Affected Bank Portfolios?" Journal of the Japanese and International Economies, vol. 7, 408-440.

Hancock, Diana, Andrew J. Laing, and James A. Wilcox [1995], "Bank Capital Shocks: Dynamic Effects on Securities, Loans, and Capital," Journal of Banking and Finance, vol. 19, pp.661-677. 
Hancock, Diana and James A. Wilcox [1994], "Bank Capital and the Credit Crunch: The Roles of Risk-Weighted and Unweighted Capital Regulation," Journal of the American Real Estate and Urban Economics Association, vol. 22, 59-94.

Haubrich, Joseph G. and Wachtel, Paul [1993], "Capital Requirements and Shifts in Commercial Bank Portfolios," Economic Review, Federal Reserve Bank of Cleveland, vol. 29, 2-15.

Jacklin, Charles [1993], "Bank Capital Requirements and Incentives for Lending," Stanford University manuscript.

Jacques, K.T. and P. Nigro [1997], "Risk-based Capital, Portfolio Risk and Bank Capital: A Simultaneous Equations Approach,” Journal of Economics and Business, vol. 49, 533-547.

Kim, Daesik and Santomero, Anthony [1988], "Risk in Banking and Capital Regulation," The Journal of Finance, vol. 43, 1219-1233.

Koehn, Michael and Santomero, Anthony [1980], "Regulation of Bank Capital and Portfolio Risk," The Journal of Finance, vol. 35, 1235-1244.

Newey, Whitney and Kenneth West [1987], "A Simple, Positive Semi-Definite, Heteroskedasticity and Autocorrelation Consistent Covariance Matrix," Econometrica, vol. 55, 703-708.

Passmore, Wayne and Steven Sharpe [1994], "Optimal Bank Portfolios and the Credit Crunch," Finance and Economics Discussion Series \# 94-19, Federal Reserve Board of Governors.

Peek, Joe and Eric S. Rosengren [1995a], "The Capital Crunch: Neither a Borrower Nor a Lender Be," Journal of Money, Credit, and Banking, vol. 27, 625-38.

Peek, Joe and Eric S. Rosengren [1995b], "Bank Regulation and the Credit Crunch," Journal of Banking and Finance, vol. 19 , 679-692.

Sharpe, Steven A. [1990], "Asymmetric Information, Bank Lending, and Implicit Contracts: A Stylized Model of Customer Relationships," The Journal of Finance, vol. 45, 1069-1087.

Shrieves, Ronald and Drew Dahl [1995], "Regulation, Recession, and Bank Lending Behavior: The 1990 Credit Crunch," Journal of Financial Services Research, vol. 9, 5-30.

Thakor, Anjan V. [1996], "Capital Requirements, Monetary Policy and Aggregate Bank Lending: Theory and Empirical Evidence," The Journal of Finance, vol. 51, 279-324.

Wall, Larry D. and David R. Peterson [1995], "Bank Holding Company Capital Targets in the Early 1990s: The Regulators Versus the Market," Journal of Banking and Finance, vol. 19, 563-574. 



\section{Recent BIS Working Papers}

No Title Author

72

August 1999

73

August 1999

74

August 1999

75

August 1999

76

October 1999

77

October 1999

78

October 1999

79

November 1999

80

November 1999

81

November 1999

82

November 1999

83

January 2000

84

January 2000

85

January 2000

86

March 2000

87

May 2000
Reserve currency allocation: an alternative methodology

The Taylor rule and interest rates in the EMU area: a note

The dollar-mark axis

A note on the Gordon growth model with nonstationary dividend growth

The price of risk at year-end: evidence from interbank lending

Perceived central bank intervention and market expectations: an empirical study of the yen/dollar exchange rate, 1993-96

Banking and commerce: a liquidity approach

Pass-through of exchange rates and import prices to domestic inflation in some industrialised economies

A note on alternative measures of real bond rates

Interbank interest rates and the risk premium

Sacrifice ratios and the conduct of monetary policy in conditions of low inflation

Switching from single to multiple bank lending relationships: determinants and implications

What have we learned from recent financial crises and policy responses?

A defence of the expectations theory as a model of US long-term interest rates

Information, liquidity and risk in the international interbank market: implicit guarantees and private credit market failure

Monetary policy in an estimated optimisation-based model with sticky prices and wages
Srichander

Ramaswamy

Stefan Gerlach and

Gert Schnabel

Gabriele Galati

Henri Pagès

Craig H Furfine

Gabriele Galati and William Melick

Joseph G Haubrich and João A C Santos

Jonathan McCarthy

Palle S Andersen

Henri Pagès

Palle S Andersen and William L Wascher

Luísa A Farinha and João A C Santos

William R White

Gregory D Sutton

Henri Bernard and Joseph Bisignano

Jeffery D Amato and Thomas Laubach 


ISSN 1020-0959 